\title{
Response of demersal fish communities to the presence of fish farms
}

\author{
A. Machias ${ }^{1, *}$, I. Karakassis ${ }^{2}$, M. Giannoulaki ${ }^{1}$, K. N. Papadopoulou ${ }^{1}$, C. J. Smith ${ }^{1}$, \\ S. Somarakis ${ }^{3}$
}

\author{
${ }^{1}$ Hellenic Centre of Marine Research, PO Box 2214, 71003 Iraklion, Crete, Greece \\ ${ }^{2}$ Department of Biology, University of Crete, PO Box 2208, 41409 Iraklion, Crete, Greece \\ ${ }^{3}$ Department of Biology, University of Patras, 26500 Patras, Greece
}

\begin{abstract}
The hypothesis that the presence of fish farms affects the communities of wild fish at large spatial scales was investigated through experimental trawl surveys. Three regions of the Aegean Sea with aquaculture zones were sampled in May and September (reproductive and recruitment periods, respectively for most species in the Aegean Sea). In each region, 2 sub-areas were sampled: 1 located nearby the fish farming zones (within 2 to $3 \mathrm{n}$ mile) and a similar site ('reference site') far away from these zones (>20 n mile). Three replicate hauls were made in each sub-area for each of the 3 investigated regions. Significant differences were observed in community structure between farming and reference sites, which were mainly due to quantitative rather than qualitative aspects. The overall abundance and/or biomass of wild demersal fish was significantly higher near the fish farms in every region studied during May without any significant change in diversity or biodiversity. During the recruitment period in September, total abundance and biomass were fairly similar. These findings support the hypothesis that the presence of fish farms affects the wild fish populations in the oligotrophic eastern Mediterranean at a spatial scale larger than the immediate vicinity of fish cages. It seems that during the recruitment period all sites were stocked with fish close to the carrying capacity of the respective areas, and by late spring the areas close to fish farming zones had suffered little losses during winter, whereas populations at the reference sites had decreased substantially.
\end{abstract}

KEY WORDS: Fish communities $\cdot$ Fisheries $\cdot$ Aquaculture $\cdot$ Mediterranean

Resale or republication not permitted without written consent of the publisher

\section{INTRODUCTION}

The expansion of fish farming in the coastal zone of the Mediterranean over the last 20 yr has raised the issue of the interaction between fish farming and fisheries, with various implications for the management of marine resources. This interaction may be addressed at various spatial scales and it is not obvious that the answer will be scale-independent. A considerable research effort has been invested over the last decades to investigate the environmental impacts of aquaculture (Gowen \& Bradburry 1987, Wu 1995, Fernandes et al. 2001). These effects are expressed at various spatial and temporal scales (Karakassis 1998), depending on the nature of the waste released, the physical, hydro- graphic and ecological characteristics of the site, and the efficiency of the management of the farms. The effects on small spatial scales (beneath or in close vicinity to cages) have been widely investigated, including effects on sediment chemistry (Holby \& Hall 1991, Hall et al. 1992, Holmer \& Kristensen 1992, Karakassis et al. 1998, Holmer et al. 2002), on benthic communities (Brown et al. 1987, Weston 1990, Mazzola et al. 1999, 2000, Karakassis et al. 2000, La Rosa et al. 2001, Mirto et al. 2002), on sea grass (Delgado et al. 1999, Pergent et al. 1999, Ruiz et al. 2001, Holmer et al. 2003), and on nutrients and plankton within the area of the farm (Pitta et al. 1999, Karakassis et al. 2001).

Most of the aforementioned studies have indicated that the effects of aquaculture on the benthic environ- 
ment are found within a short distance, normally not exceeding 25 to $30 \mathrm{~m}$ from the edge of fish cages; however, it is well known that fish farming releases a substantial amount of nutrients into the marine environment (Holby \& Hall 1991, Hall et al. 1992) and it would, therefore, be reasonable to expect effects at larger spatial scales, particularly when a zone of farms is established in a coastal bay. Such large scale effects have been reported by Pohle et al. (2001) from the Canadian coast, showing signs of stress for benthic macrofauna at distances $>200 \mathrm{~m}$ from any fish farm in that area. Effects on wild fish have been investigated at very short spatial scales (Carss 1990, 1994, Dempster et al. 2002), indicating a considerable increase in wild fish abundance and biomass in the immediate vicinity of fish cages. However, it is not known whether such changes also affect fish communities in the broader area surrounding aquaculture development zones and particularly in oligotrophic environments where nutrient scarcity limits productivity including fisheries production. This type of information would be important in order to estimate the potential negative or positive effects of aquaculture on coastal fisheries and, therefore, to conclude whether there is an objective basis for conflict between these 2 important uses of the coastal zone.

In the present study, we investigated the effect of the presence of fish farms on marine biota of wild fish in 3 areas in the Aegean Sea. The objective of this study was to test the hypothesis that the presence of fish farms, and the associated change in the fluxes of nutrients and organic material, could cause a large-scale effect on fish communities in the area of an aquaculture zone.

\section{MATERIALS AND METHODS}

The study areas. The effect of fish farming on wild fish populations was studied in 3 regions (Evia Island, Lesvos Island and Chios Island) in the Aegean Sea (Eastern Mediterranean basin). In each region (Fig. 1), 1 sub-area near the zone of fish farming activity (hereafter referred to as 'fish-farm site') and 1 sub-area far away from these zones (hereafter referred to as 'reference site') were investigated in May 2001 and September 2002. Sea bream and sea bass were the reared species at all fish farm sites. The first sampling took place before the closed period for trawling in Greece and during the reproduction period for most of the commercial fish species (Stergiou et al. 1997), while the second sampling took place before the open period for trawling and during the recruitment period for most of the fish species. Reference sites had comparable topography, depth and an average distance of $20 \mathrm{n}$



Fig. 1. Sampling areas (E: Evia; C: Chios; L: Lesvos islands) and sites (N: near; F: far). Latitude and longitude in decimal minutes. X: trawl sampling; $\bullet$ : fish farms; fi: finer sediment (substrate with more than $40 \%$ silt and clay); co: coarser sediment (substrate with less than $40 \%$ silt and clay)

miles from the respective fish-farm sites. At all 6 sites, the substrates were mud and sand mixed with maerl in different ratios. For data analysis, the substrates with more than $40 \%$ silt and clay were classified as 'fine' and the others as 'coarse' (Fig. 1).

Sampling design. During each sampling survey, 3 replicate hauls were made at each site using an otter trawl with a cod-end bag liner of $28 \mathrm{~mm}$ stretched mesh-size. At the fish farm sites, the samples were collected at a distance of 2 to $3 \mathrm{n}$ miles from the cages, while at the reference sites, the samples were collected at similar depths (70 to $80 \mathrm{~m}$ ) to fish farm sites (Fig. 2). The haul duration ranged between 40 and $45 \mathrm{~min}$, and towing speed between 2.8 and 3 knots. The door spread of the trawl net was calculated for each haul based on the method of Carrothers (1980). The total area swept was calculated by multiplying the door 


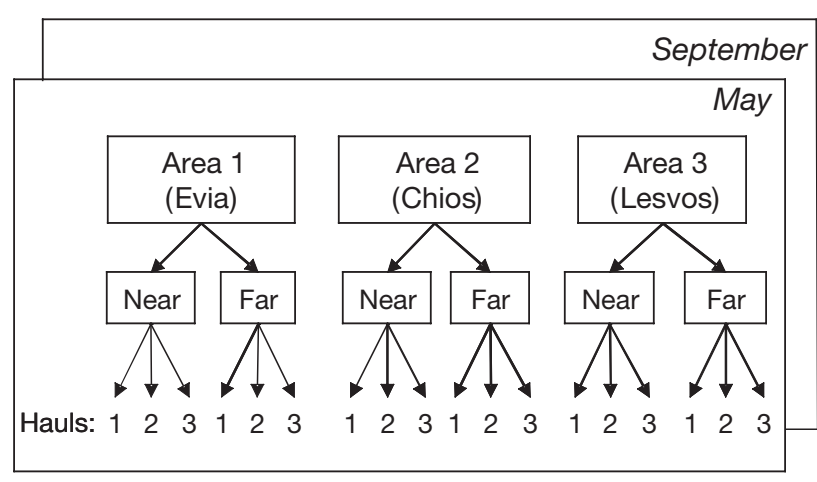

Fig. 2. Sampling design $(2$ seasons $\times 3$ areas $\times 2$ sites $\times 3$ replicates)

spread by the vessel speed and the fishing time. Fish species abundance and biomass were expressed as number of fish or biomass (g) per $\mathrm{km}^{2}$.

Data analysis. To test the effects of aquaculture on the fish communities, the following measures were calculated: number of species per haul $(S)$. Since the number of species is sensitive to the total abundance, we also used the Shannon-Wiener diversity $\left(H^{\prime}\right)$ and the $J$ evenness indices, which standardise the sample size with respect to abundance and species number. Furthermore, we calculated the Simpson $(1-\lambda)$ index (i.e. dominance), which is known to be one of the least affected by sample size (Karakassis et al. 1996). In addition, the new biodiversity indices $\left(\Delta^{*}, \Delta+, \mathrm{s} \Delta+\right.$, $\lambda+$ ), based on taxonomic distinctness (Warwick \& Clarke 1995, Clarke \& Warwick 1998), were calculated. Taxonomic distinctness $\left(\Delta^{*}\right)$ is the average path length between 2 randomly chosen individuals from the sample, conditional on them being of different species. This is a measure of the average degree to which individuals in an assemblage are related to each other (Warwick \& Clarke 1995). Average taxonomic distinctness $(\Delta+)$ is the mean path length through the taxonomic tree connecting every pair of species in the tree (Clarke \& Warwick 1998). It is calculated by summing the path lengths through a taxonomic tree between every pair of species in the list, and dividing by the number of paths. Total taxonomic distinctness (s $\Delta+$ ) is the sum (over all species) of the average distance of each species to all other species. It provides an estimate of the total taxonomic distinctness of the tree of the species present in the community. Finally, variation in taxonomic distinctness $(\lambda+)$ is the variance of the pairwise path lengths between every pair of species in the list, reflecting the unevenness of the taxonomic tree. Multivariate analysis of fish community data (double square-root transformation) involved the use of the Bray-Curtis similarity index, and cluster and MDS analyses. The contribution of each species to the average Bray-Curtis dissimilarity between groups of combinations as well as to the average Bray-Curtis similarity within a group of combinations, was identified using SIMPER analysis (Clarke \& Warwick 1994). All these analyses were carried out by means of the PRIMER-5 software (Clarke \& Warwick 1994).

The log-transformed abundance and biomass data as well as the diversity and biodiversity indices were compared by means of analysis of variance (ANOVA) after checking for homogeneity of variance (Zar 1984). The comparisons included region, fish farm presence and substrate per season.

\section{RESULTS}

\section{Abundance and biomass}

ANOVA for total abundance and biomass of the wild fish communities (Fig. 3) showed that both parameters were consistently and significantly higher at the fish farm site during May. However, this was not the case for September, i.e. during the recruitment period (Table 1, Fig. 3).
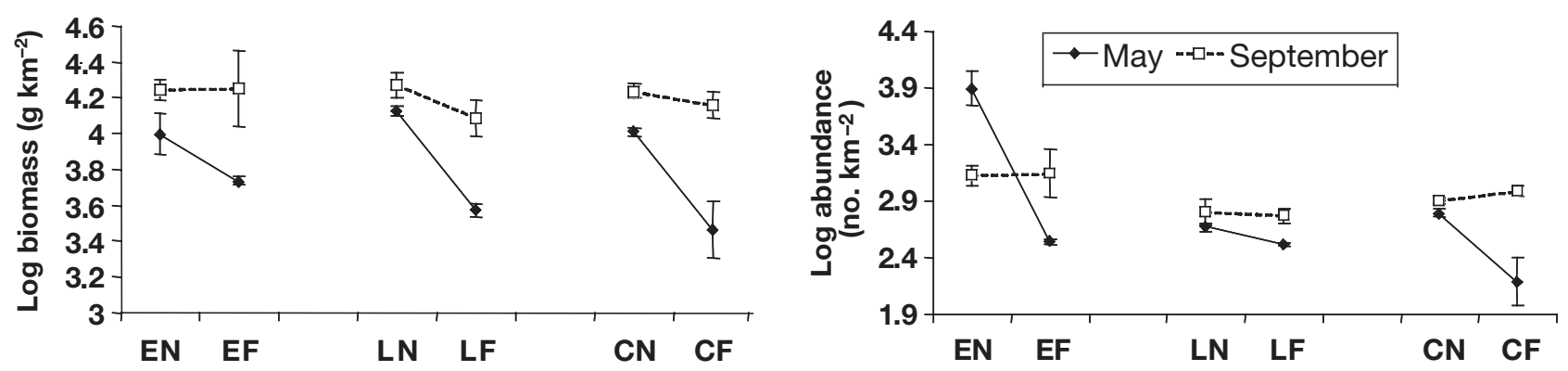

Fig. 3. Fish biomass and fish abundance (log-transformed) per season (May, September), per area and presence of fish farm (near, far). E: Evia Island; L: Lesvos Island; C: Chios Island; N: near; F: far. Average data and the $95 \%$ confidence intervals for 3 replicates are given 
Table 1. ANOVA table for fish biomass and fish abundance, including $S$ (number of species per haul), $J$ (evenness index), $H^{\prime}$ (Shannon-Wiener diversity index), $1-\lambda$ (Simpson index), $\Delta^{*}$ (taxonomic distinctness), $\Delta^{+}$(average taxonomic distinctness), s $\Delta+$ (total taxonomic distinctness) and $\lambda+$ (variation in taxonomic distinctness), for each season separately (May, September). Region, fish-farm presence (cages) and substrate type were the factors considered. p: probability. Significant probabilities in bold

\begin{tabular}{|c|c|c|c|c|c|c|c|}
\hline & & & — May & & \multicolumn{3}{|c|}{ September } \\
\hline & & Region & Cages & Substrate & Region & Cages & Substrate \\
\hline \multirow[t]{2}{*}{ Biomass } & $F$ & 1.55 & 49.36 & 1.15 & 0.93 & 0.98 & 1.51 \\
\hline & $\mathrm{p}$ & 0.248 & 0.00 & 0.303 & 0.420 & 0.341 & 0.241 \\
\hline \multirow[t]{2}{*}{ Abundance } & $F$ & 1.48 & 5.6 & 2.31 & 6.87 & 0.02 & 0.26 \\
\hline & $\mathrm{p}$ & 0.264 & 0.034 & 0.153 & 0.009 & 0.896 & 0.616 \\
\hline \multirow[t]{2}{*}{$S$} & $F$ & 10.3 & 15.44 & 58.44 & 4.02 & 0.55 & 14.48 \\
\hline & $\mathrm{p}$ & 0.002 & 0.002 & 0.000 & 0.044 & 0.470 & 0.022 \\
\hline \multirow[t]{2}{*}{$J$} & $F$ & 8.57 & 1.21 & 1.84 & 6.1 & 0.03 & 0.88 \\
\hline & $\mathrm{p}$ & 0.004 & 0.291 & 0.198 & 0.014 & 0.864 & 0.365 \\
\hline \multirow[t]{2}{*}{$H^{\prime}$} & $F$ & 13.47 & 0 & 0.28 & 16.21 & 0.42 & 16.86 \\
\hline & $\mathrm{p}$ & 0.001 & 0.978 & 0.604 & 0.000 & 0.530 & 0.001 \\
\hline \multirow[t]{2}{*}{$1-\lambda$} & $F$ & 8.32 & 0.06 & 0.93 & 5.44 & 0 & 7.4 \\
\hline & $\mathrm{p}$ & 0.005 & 0.812 & 0.352 & 0.019 & 0.954 & 0.018 \\
\hline \multirow[t]{2}{*}{$\Delta^{*}$} & $F$ & 0.29 & 5.82 & 17.41 & 1.07 & 0.14 & 8.06 \\
\hline & $\mathrm{p}$ & 0.755 & 0.031 & 0.001 & 0.371 & 0.711 & 0.014 \\
\hline \multirow[t]{2}{*}{$\Delta+$} & $F$ & 1.67 & 0.39 & 0.57 & 8.68 & 0.45 & 2.3 \\
\hline & $\mathrm{p}$ & 0.226 & 0.545 & 0.462 & 0.004 & 0.513 & 0.153 \\
\hline \multirow[t]{2}{*}{$\mathrm{s} \Delta+$} & $F$ & 6 & 7.88 & 37.97 & 5.54 & 0.92 & 16.12 \\
\hline & $\mathrm{p}$ & 0.014 & 0.015 & 0.000 & 0.018 & 0.356 & 0.002 \\
\hline \multirow[t]{2}{*}{$\lambda_{+}$} & $F$ & 7.23 & 0.59 & 0.13 & 6.09 & 0.05 & 2.62 \\
\hline & $\mathrm{p}$ & 0.077 & 0.458 & 0.722 & 0.014 & 0.821 & 0.130 \\
\hline
\end{tabular}

\section{Diversity}

The number of fish species showed significant differences with region, substrate and presence of fish farming during May (Table 1). In all cases, the number of fish species at the fish farm site was higher than at the respective reference stations (Fig. 4). The number of fish species was not significantly different between fish farm and reference sites during September.

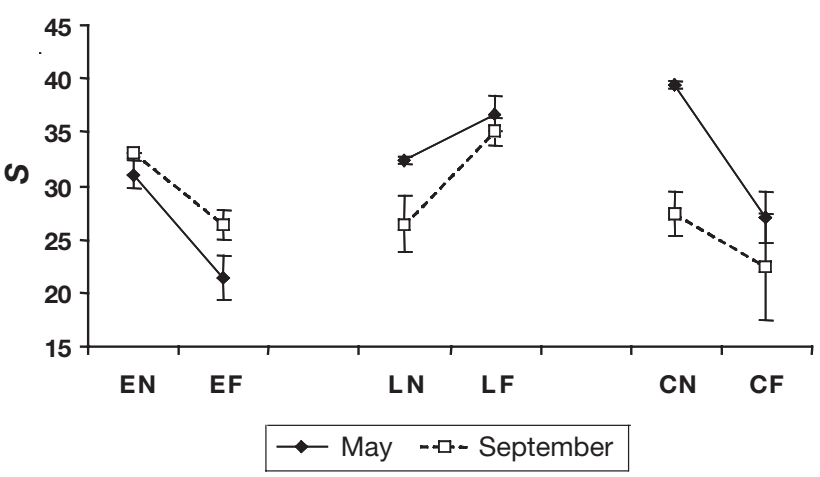

Fig. 4. The number of species per haul $(S)$ per season (May, September), per area and fish farm presence (near, far). E: Evia Island; L: Lesvos Island; C: Chios Island; N: near; F: far. Average data and the $95 \%$ confidence intervals for 3 replicates are given
$H^{\prime}$ and $J$ indices (Table 1), which standardise the sample size with respect to abundance and species number, showed no significant difference in diversity with respect to the presence of fish farms.

Among the biodiversity indices, $\Delta^{*}$ and the total path length between any 2 randomly-chosen fish species $(\mathrm{s} \Delta+)$ showed a significant increase at the fish farm sites during May, but again no significant differences during September.

\section{Multivariate analysis}

Cluster analysis on both the abundance and biomass data matrices (dendrogram not shown here) defined 2 major groups of hauls related to sediment type. Within these 2 major clusters, there were several sub-groups reflecting other sources of variability such as season, area and presence of fish farms. The results of MDS (Fig. 5) also showed similar groupings with respect to sediment type, season and presence of fish farms. The 2-way ANOSIM (Table 2) performed for all different combinations of the parameters examined (i.e. season, substrate and presence of fish farms) showed that proximity to aquaculture zones was 1 of the factors affecting the similarities among sampling stations. In other words, within groups of the same season, or sub- 
Abundance
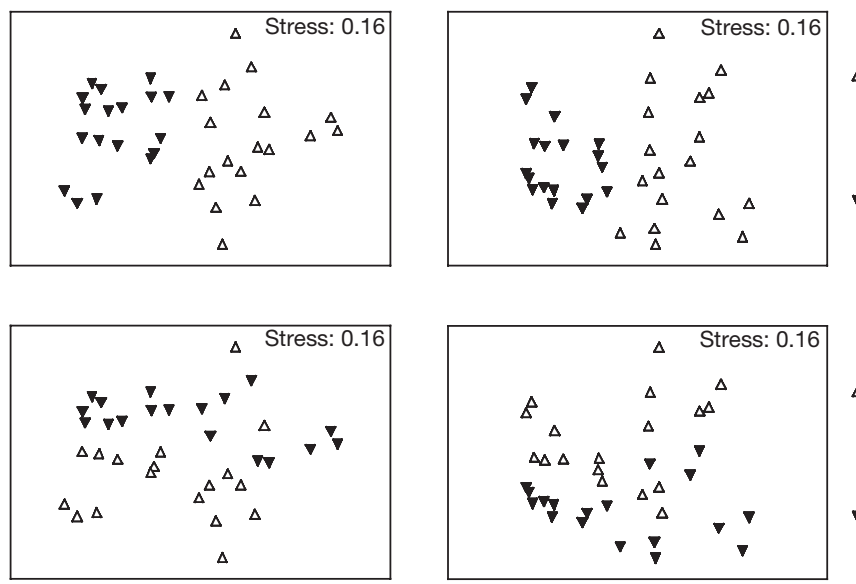

$\triangle$ May
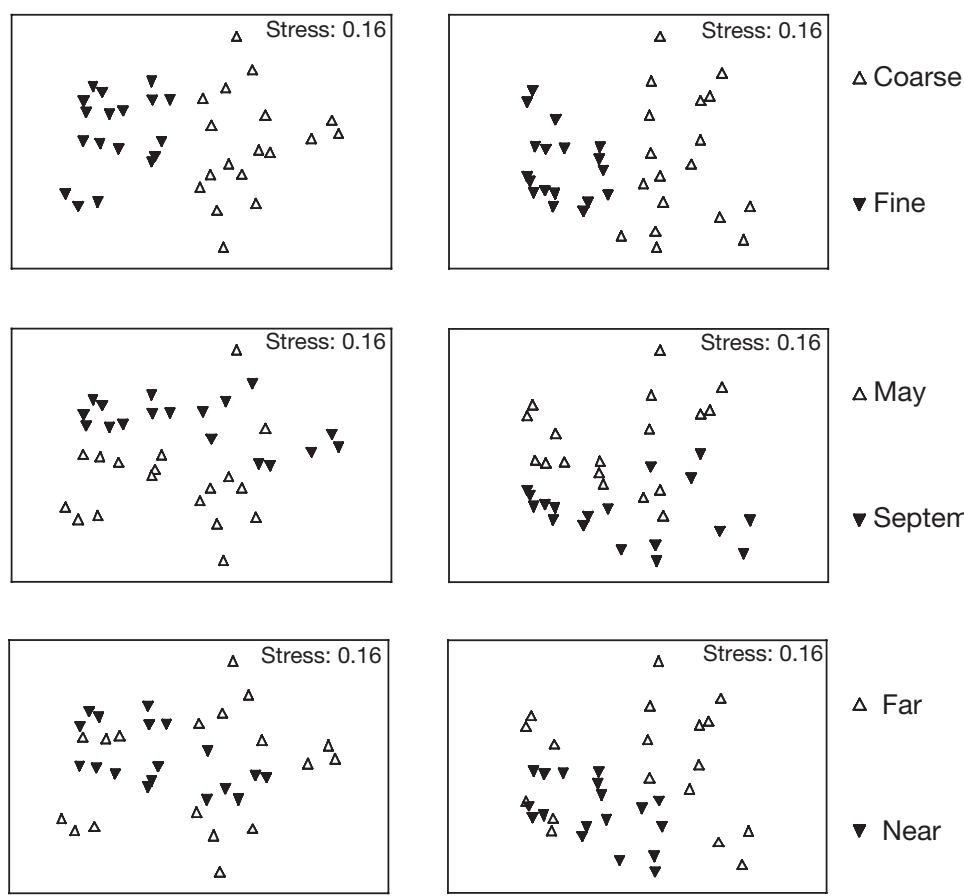

Fig. 5. MDS analysis of fish abundance and fish biomass. Different symbols distinguish between substratum type (fine, coarse), season (May, September) and fish-farm presence (near, far)

strate type or region, the proximity to fish cages played a role in determining the community structure in terms of abundance per species or biomass per species (with the exception of the combination cages $x$ substrate in terms of biomass).

The SIMPER analysis on species abundance data (Tables $3 \& 4$ ) was used to detect the main community attributes responsible for the similarities and dissimilarities among stations, i.e. which species were responsible for the qualitative and quantitative differences that caused an increase in dissimilarity among stations taken at different seasons, substrate types, regions or presence/absence of fish farms. In almost all cases, the results pointed to quantitative (levels of abundance) rather than qualitative (presence/ absence of a species) differences in community structure. This was the case regarding proximity to fish farms (Table 4), where dissimilarities were mainly due to changes in the abundance of 17 species, among which, 12 were more abundant at the fish farm sites and 5 were less abundant. Among those species with increased abundance were commercial species important to local fisheries such as Mullus barbatus (average increase in abundance $56 \%$ ), Merluccius merluccius (+97\%), Pagellus acarne (+159\%) and Diplodus annularis $(+504 \%)$. The SIMPER analysis was also performed on the species-biomass data (Table 5), showing

Table 2. ANOSIM table for fish abundance and biomass per season (May, September), Region (Evia, Lesvos, Chios), fish-farm presence (cages) and substrate. $R$ : ANOSIM $R$ statistic; p: probability. Significant probabilities in bold

\begin{tabular}{|c|c|c|c|c|c|c|}
\hline \multirow[t]{2}{*}{ Analysis } & & & \multicolumn{2}{|c|}{ Abundance } & \multicolumn{2}{|c|}{ Biomass } \\
\hline & & & $R$ & $\mathrm{p}$ & $R$ & $\mathrm{p}$ \\
\hline Season $\times$ Region & $\begin{array}{l}\text { Season } \\
\text { Region }\end{array}$ & $\begin{array}{l}\text { Evia-Lesvos } \\
\text { Evia-Chios } \\
\text { Lesvos-Chios }\end{array}$ & $\begin{array}{l}0.303 \\
0.239 \\
0.177 \\
0.249 \\
0.311\end{array}$ & $\begin{array}{l}\mathbf{0 . 0 0 7} \\
\mathbf{0 . 0 0 2} \\
0.067 \\
\mathbf{0 . 0 1 8} \\
\mathbf{0 . 0 0 6}\end{array}$ & $\begin{array}{l}0.481 \\
0.259 \\
0.194 \\
0.203 \\
0.365\end{array}$ & $\begin{array}{l}0.100 \\
\mathbf{0 . 0 0 2} \\
\mathbf{0 . 0 4 8} \\
\mathbf{0 . 0 4 0} \\
\mathbf{0 . 0 0 2}\end{array}$ \\
\hline Season $\times$ Cages & $\begin{array}{l}\text { Season } \\
\text { Cages }\end{array}$ & & $\begin{array}{l}0.204 \\
0.179\end{array}$ & $\begin{array}{l}0.014 \\
0.017\end{array}$ & $\begin{array}{l}1.000 \\
0.228\end{array}$ & $\begin{array}{l}0.333 \\
\mathbf{0 . 0 0 3}\end{array}$ \\
\hline Season $\times$ Substrate & $\begin{array}{l}\text { Season } \\
\text { Substrate }\end{array}$ & & $\begin{array}{l}0.386 \\
0.764\end{array}$ & $\begin{array}{l}0.001 \\
0.001\end{array}$ & $\begin{array}{l}0.500 \\
0.689\end{array}$ & $\begin{array}{l}0.667 \\
\mathbf{0 . 0 0 1}\end{array}$ \\
\hline Region $\times$ Cages & Region & $\begin{array}{l}\text { Evia-Lesvos } \\
\text { Evia-Chios } \\
\text { Lesvos-Chios }\end{array}$ & $\begin{array}{l}0.861 \\
0.974 \\
0.679 \\
0.954 \\
0.867\end{array}$ & $\begin{array}{l}0.001 \\
0.001 \\
0.001 \\
0.001 \\
0.001\end{array}$ & $\begin{array}{r}-0.111 \\
0.000 \\
0.250 \\
-0.750 \\
0.823\end{array}$ & $\begin{array}{l}0.667 \\
0.667 \\
0.667 \\
1.000 \\
\mathbf{0 . 0 0 1}\end{array}$ \\
\hline Region $\times$ Substrate & Substrate & $\begin{array}{l}\text { Evia-Lesvos } \\
\text { Evia-Chios } \\
\text { Lesvos-Chios }\end{array}$ & $\begin{array}{l}0.581 \\
0.515 \\
0.679 \\
0.614 \\
0.867\end{array}$ & $\begin{array}{l}0.001 \\
0.001 \\
0.001 \\
0.001 \\
0.001\end{array}$ & $\begin{array}{r}-0.111 \\
0.000 \\
0.250 \\
-0.750 \\
0.823\end{array}$ & $\begin{array}{l}0.667 \\
0.667 \\
0.667 \\
1.000 \\
\mathbf{0 . 0 0 1}\end{array}$ \\
\hline Cages $\times$ Substrate & $\begin{array}{l}\text { Cages } \\
\text { Substrate }\end{array}$ & & $\begin{array}{l}0.290 \\
0.879\end{array}$ & $\begin{array}{l}0.001 \\
0.001\end{array}$ & $\begin{array}{r}-0.500 \\
0.827\end{array}$ & $\begin{array}{l}1.000 \\
\mathbf{0 . 0 0 1}\end{array}$ \\
\hline
\end{tabular}


Table 3. SIMPER analysis for fish abundance per substrate type (coarse, fine). Av. abund.: average abundance; av. sim.: average similarity; cum. sim. $(\%)$ : cumulative percentage of similarity

\begin{tabular}{|c|c|c|c|c|}
\hline Species & $\begin{array}{l}\text { Av. abund. } \\
\text { Coarse }\end{array}$ & $\begin{array}{l}\text { Av. abund. } \\
\text { Fine }\end{array}$ & Av. sim. & $\begin{array}{c}\text { Cum. sim. } \\
(\%)\end{array}$ \\
\hline \multicolumn{5}{|l|}{ Average similarity: $\mathbf{5 7 . 5 8} \%$} \\
\hline Serranus hepatus & 56.59 & & 4.81 & 8.36 \\
\hline Spicara maena & 108.10 & & 4.67 & 16.47 \\
\hline Chelidonichthys lastoviza & 44.55 & & 4.48 & 24.25 \\
\hline Mullus barbatus & 46.21 & & 4.22 & 31.58 \\
\hline Citharus linguatula & 16.24 & & 3.77 & 38.12 \\
\hline Serranus cabrilla & 18.05 & & 3.76 & 44.66 \\
\hline Spicara smaris & 123.62 & & 3.27 & 50.33 \\
\hline Pagellus erythrinus & 15.51 & & 3.14 & 55.79 \\
\hline Lepidotrigla cavillone & 43.57 & & 3.00 & 61.00 \\
\hline \multicolumn{5}{|l|}{ Average similarity: $64.74 \%$} \\
\hline Serranus hepatus & & 149.95 & 5.58 & 8.62 \\
\hline Arnoglossus laterna & & 76.29 & 4.83 & 16.08 \\
\hline Citharus linguatula & & 140.67 & 4.56 & 23.13 \\
\hline Mullus barbatus & & 66.76 & 4.13 & 29.51 \\
\hline Lesueurigobius friesii & & 62.79 & 3.31 & 34.62 \\
\hline Spicara maena & & 20.91 & 3.15 & 39.49 \\
\hline Lepidotrigla cavillone & & 39.43 & 3.02 & 44.15 \\
\hline Merluccius merluccius & & 16.79 & 2.99 & 48.77 \\
\hline Cepola macrophthalma & & 43.68 & 2.68 & 52.92 \\
\hline Serranus cabrilla & & 15.14 & 2.42 & 56.66 \\
\hline Trisopterus minutus capelanus & & 28.7 & 2.27 & 60.17 \\
\hline Pagellus erythrinus & & 8.29 & 2.22 & 63.59 \\
\hline Uranoscopus scaber & & 1.86 & 1.83 & 66.41 \\
\hline \multicolumn{5}{|l|}{ Average dissimilarity: $52.09 \%$} \\
\hline Lesueurigobius friesii & 0.46 & 62.79 & 2.44 & 4.69 \\
\hline Arnoglossus laterna & 18.1 & 76.29 & 2.14 & 8.79 \\
\hline Spicara smaris & 123.62 & 0.27 & 2.09 & 12.82 \\
\hline Cepola macrophthalma & 0 & 43.68 & 2.05 & 16.76 \\
\hline Trisopterus minutus capelanus & 6.1 & 28.70 & 1.76 & 20.14 \\
\hline Mullus surmuletus & 74.96 & 0.38 & 1.61 & 23.23 \\
\hline Arnoglossus thori & 22.19 & 0.88 & 1.60 & 26.30 \\
\hline Citharus linguatula & 16.24 & 140.67 & 1.44 & 29.06 \\
\hline Trachurus trachurus & 42.46 & 9.69 & 1.36 & 31.67 \\
\hline Merluccius merluccius & 0.63 & 16.79 & 1.35 & 34.27 \\
\hline Chelidonichthys lastoviza & 44.55 & 1.14 & 1.29 & 36.74 \\
\hline Lepidotrigla cavillone & 43.57 & 39.43 & 1.27 & 39.17 \\
\hline Spicara maena & 108.1 & 20.91 & 1.20 & 41.48 \\
\hline Pagellus acarne & 12.3 & 6.49 & 1.18 & 43.75 \\
\hline Serranus hepatus & 56.59 & 149.95 & 1.14 & 45.93 \\
\hline Diplodus annularis & 10.71 & 4.84 & 1.10 & 48.04 \\
\hline Boops boops & 12.84 & 1.08 & 1.09 & 50.12 \\
\hline Engraulis encrasicolus & 0 & 6.31 & 1.08 & 52.19 \\
\hline
\end{tabular}

similar results. In this case, 19 species were found to collectively account for $49 \%$ of the dissimilarity among stations. Only 3 showed low abundance at the fish farm sites: Spicara smaris (-93\%), Trachurus trachurus $(-82 \%)$ and Mullus surmuletus (-74\%), whereas the remaining 16 species showed an increase in biomass ranging from 10 to $1100 \%$.

\section{DISCUSSION}

In all 3 regions studied, the total abundance and biomass at the putative impacted zone was significantly higher than at the respective reference sites during May. The consistency of this finding supports the hypothesis of a positive effect of fish farming on the wild fish populations, at a spatial scale larger than the immediate vicinity of fish cages. However, total abundance and biomass were fairly similar between the fish-farm and reference sites during the recruitment period in September. It is likely that during the recruitment period, all sites (fish-farm and reference) are stocked with fish close to the carrying capacity of the respective areas. It is also worth noting that the September survey was carried out at nearly the end of the 4 mo closed season for trawls in the Aegean Sea and, therefore, there was a small effect of fishing on demersal species.

By late spring, the zones in the vicinity to fish farm activities had suffered lower winter losses than those at the reference sites, where fish populations had decreased substantially. Caddy (1993) reports that fishery production for formerly oligotrophic seas has increased in recent decades, which can be attributed to moderate enrichment from land. Our data seem to support the hypothesis that fish farming could also be expected to increase fish production in certain oligotrophic ecosystems. This increase cannot be attributed to the consumption of the unused feed pellets beneath fish farms. It is shown here that the fish species responsible for the increase in abundance near fish farms are not those usually found beneath cages in the Mediterranean Sea (Dempster et al. 2002, Smith et al. 2003), which are likely to feed on particulate wastes from the fish farms. A possible reason for the increase could be either an increase in primary production due to increased supply of dissolved nutrient wastes from the fish farms and/or a local reduction in fishing pressure due to occupation of part of coastal space by the fish farms.

Although inter-annual variability could partly explain the observed differences among seasons, there are other independent indications that the presence of fish farms has an overall positive effect on wild fish communities such as the increasing trend of landings in the investigated areas after the establishment of fish farms in the early 1990s (Machias et al. 2003), as well as the significant increase in fish abundance after the establishment of aquaculture in the case of Evia island (Machias et al. 2004). 
Two hypotheses could explain the observed differences between the 2 sampling seasons. The first could be that the fish populations inhabiting the wider area are attracted by the floating structures (cages), or by the odour of the food used in fish farms and, therefore, reach higher densities at the fish farm sites. Subsequently, as fish populations decline from September to May, because of natural and/or fishing mortality, the sites near the fish farms are constantly replenished with additional fish biomass from the surrounding area, thereby remaining close to carrying capacity. This hypothesis, however, hardly explains the increase seen in landings after the onset of aquaculture (Machias et al. 2003).

Alternatively, the differences between the fish farm and the reference sites were present in September (recruitment period for most of the species, Stergiou et al. 1997) as well, but they were not detectable under the applied sampling scheme. It is well known that the recruitment for most of the species in the surveyed areas, takes place in shallow water near the coastline (depth $<60 \mathrm{~m}$ ). Although there is always an overlap of juveniles and adults, the majority of juveniles stay in shallow waters, while adults remain in deep waters after their first maturation, usually in spring (Tsimenides et al. 1992, Machias et al. 1998, Labropoulou et al. 1999, Machias \& Labropoulou 2002, Somarakis \& Machias 2002). The presence of fish farms could result in a higher degree of habitat separation between juvenile and adults, as well as in an increase in the residence time of juveniles near the coast. As, in the framework of the present study, we investigated the adult habitat (depths $>70 \mathrm{~m}$ ), the density of juveniles could have been underestimated. At the reference sites, the lower resources and higher competition, could have imposed a higher dispersion of juveniles, and a higher overlap of juvenile and adult habitats. The difference in density and/or abundance between fish-farm and reference sites was more obvious during spring (reproductive period for most of the species, Stergiou et al. 1997), when the fish move to deeper waters. The effect of fish cages presence on local recruitment needs further and more targeted research.

The study of diversity, as expressed by different indices, showed no significant effect in response to the incidence of fish farming. In other words, the observed
Table 4. SIMPER analysis for fish abundance per fish-farm presence (fishfarm site, reference site). Av. abund.: average abundance; av. sim.: average similarity; cum. sim. (\%): cumulative percentage of similarity

\begin{tabular}{|c|c|c|c|c|}
\hline Species & $\begin{array}{l}\text { Av. abund. } \\
\text { Reference }\end{array}$ & $\begin{array}{l}\text { Av. abund. } \\
\text { Fish-farm }\end{array}$ & Av. sim. & $\underset{(\%)}{\text { Cum. sim. }}$ \\
\hline \multicolumn{5}{|l|}{ Average similarity: $51.53 \%$} \\
\hline Serranus hepatus & 63.87 & & 5.88 & 11.41 \\
\hline Mullus barbatus & 44.11 & & 4.08 & 19.34 \\
\hline Citharus linguatula & 22.77 & & 3.95 & 27.01 \\
\hline Spicara maena & 65.67 & & 3.73 & 34.26 \\
\hline Chelidonichthys lastoviza & 36.81 & & 3.32 & 40.69 \\
\hline Serranus cabrilla & 12.36 & & 2.95 & 46.42 \\
\hline Pagellus erythrinus & 15.45 & & 2.68 & 51.62 \\
\hline \multicolumn{5}{|l|}{ Average similarity: $\mathbf{6 0 . 7 0 \%}$} \\
\hline Serranus hepatus & & 142.67 & 4.54 & 7.48 \\
\hline Mullus barbatus & & 68.85 & 4.26 & 14.5 \\
\hline Lepidotrigla cavillone & & 61.94 & 4.25 & 21.5 \\
\hline Citharus linguatula & & 134.14 & 4.20 & 28.41 \\
\hline Spicara maena & & 63.34 & 3.90 & 34.83 \\
\hline Serranus cabrilla & & 20.82 & 3.18 & 40.08 \\
\hline Pagellus erythrinus & & 8.35 & 2.68 & 44.49 \\
\hline Merluccius merluccius & & 11.56 & 2.36 & 48.37 \\
\hline Arnoglossus laterna & & 57.86 & 2.25 & 52.08 \\
\hline Chelidonichthys lastoviza & & 8.88 & 2.11 & 55.55 \\
\hline Pagellus acarne & & 13.55 & 2.00 & 58.84 \\
\hline Blennius ocellaris & & 2.50 & 1.85 & 61.88 \\
\hline \multicolumn{5}{|l|}{ Average dissimilarity: $47.33 \%$} \\
\hline Spicara smaris & 118.07 & 5.83 & 1.79 & 3.79 \\
\hline Lesueurigobius friesii & 7.56 & 55.69 & 1.74 & 7.47 \\
\hline Arnoglossus laterna & 36.53 & 57.86 & 1.60 & 10.85 \\
\hline Cepola macrophthalma & 1.31 & 42.37 & 1.45 & 13.91 \\
\hline Trisopterus minutus capelanus & IS 21.91 & 12.89 & 1.45 & 16.97 \\
\hline Lepidotrigla cavillone & 21.05 & 61.94 & 1.44 & 20.01 \\
\hline Pagellus acarne & 5.24 & 13.55 & 1.42 & 23.02 \\
\hline Mullus surmuletus & 67.77 & 7.58 & 1.34 & 25.85 \\
\hline Citharus linguatula & 22.77 & 134.14 & 1.34 & 28.68 \\
\hline Arnoglossus thori & 8.30 & 14.77 & 1.29 & 31.39 \\
\hline Trachurus trachurus & 46.54 & 5.61 & 1.26 & 34.06 \\
\hline Spicara maena & 65.67 & 63.34 & 1.19 & 36.57 \\
\hline Diplodus annularis & 2.21 & 13.34 & 1.15 & 39.00 \\
\hline Serranus hepatus & 63.87 & 142.67 & 1.13 & 41.37 \\
\hline Merluccius merluccius & 5.86 & 11.56 & 1.07 & 43.64 \\
\hline Mullus barbatus & 44.11 & 68.85 & 1.04 & 45.84 \\
\hline Callionymus maculatus & 3.42 & 4.02 & 1.00 & 47.95 \\
\hline
\end{tabular}

increase in abundance was not accompanied by a simplification of the community: both the number of species and the distinctness-based biodiversity indices $\left(\Delta^{*}\right)$ and $(\mathrm{s} \Delta+)$ showed an increase at the fish farm sites in comparison to the reference sites. The same trend has been observed when comparing the period before and after the aquaculture establishment in the region of Evia island (Machias et al. 2004), with these 2 biodiversity indices being higher after the establishment of fish farms in comparison to the 'before' period. As opposed to 'standard' diversity indices, which look into whether individuals belong to the same species, lack explicit links to functional diversity (Clarke \&Warwick 1998) and are largely effort-dependent (Clarke \& Warwick 1999), biodiversity indices measure the degree to which species are taxonomically related to each other 
Table 5. SIMPER analysis for fish biomass per fish-farm presence (fish-farm site, reference site). Av. biom: average biomass; av. sim: average similarity; cum. sim. (\%): cumulative percentage of similarity

\begin{tabular}{|c|c|c|c|c|}
\hline Species & $\begin{array}{l}\text { Av. biom. } \\
\text { Reference }\end{array}$ & $\begin{array}{l}\text { Av. biom. } \\
\text { Fish-farm }\end{array}$ & Av. sim. & $\begin{array}{c}\text { Cum. sim. } \\
(\%)\end{array}$ \\
\hline \multicolumn{5}{|l|}{ Average similarity: $51.16 \%$} \\
\hline Serranus hepatus & 562.35 & & 4.96 & 9.70 \\
\hline Mullus barbatus & 1199.08 & & 4.65 & 18.79 \\
\hline Spicara maena & 1302.81 & & 4.11 & 26.83 \\
\hline Chelidonichthys lastoviza & 627.35 & & 3.36 & 33.40 \\
\hline Serranus cabrilla & 376.20 & & 3.23 & 39.73 \\
\hline Pagellus erythrinus & 317.09 & & 3.08 & 45.74 \\
\hline Citharus linguatula & 268.15 & & 2.90 & 51.40 \\
\hline \multicolumn{5}{|l|}{ Average similarity: $61.95 \%$} \\
\hline Mullus barbatus & & 2056.73 & 4.76 & 7.68 \\
\hline Citharus linguatula & & 1649.42 & 3.96 & 14.07 \\
\hline Spicara maena & & 1530.97 & 3.90 & 20.35 \\
\hline Serranus cabrilla & & 958.82 & 3.70 & 26.32 \\
\hline Merluccius merluccius & & 731.69 & 3.67 & 32.24 \\
\hline Serranus hepatus & & 1391.33 & 3.62 & 38.09 \\
\hline Lepidotrigla cavillone & & 759.15 & 3.61 & 43.91 \\
\hline Pagellus erythrinus & & 437.59 & 3.23 & 49.12 \\
\hline Chelidonichthys lastoviza & & 275.66 & 2.42 & 53.02 \\
\hline Pagellus acarne & & 565.48 & 2.05 & 56.33 \\
\hline Uranoscopus scaber & & 115.57 & 1.93 & 59.45 \\
\hline Echelus myrus & & 54.41 & 1.92 & 62.56 \\
\hline \multicolumn{5}{|l|}{ Average dissimilarity: $\mathbf{4 7 . 2 8} \%$} \\
\hline Spicara smaris & 1966.17 & 143.37 & 1.69 & 3.57 \\
\hline Pagellus acarne & 133.21 & 565.48 & 1.60 & 6.95 \\
\hline Merluccius merluccius & 443.04 & 731.69 & 1.47 & 10.06 \\
\hline Mullus surmuletus & 1174.02 & 302.97 & 1.35 & 12.91 \\
\hline Citharus linguatula & 268.15 & 1649.42 & 1.34 & 15.74 \\
\hline Trisopterus minutus capelanus & 184.34 & 322.37 & 1.32 & 18.54 \\
\hline Lophius budegassa & 161.87 & 505.76 & 1.30 & 21.28 \\
\hline Cepola macrophthalma & 39.88 & 489.75 & 1.28 & 24.00 \\
\hline Lepidotrigla cavillone & 228.63 & 759.15 & 1.27 & 26.69 \\
\hline Diplodus annularis & 80.90 & 423.10 & 1.26 & 29.35 \\
\hline Trachurus trachurus & 565.85 & 103.74 & 1.14 & 31.77 \\
\hline Spicara maena & 1302.81 & 1530.97 & 1.14 & 34.18 \\
\hline Boops boops & 223.57 & 247.02 & 1.06 & 36.41 \\
\hline Serranus cabrilla & 376.20 & 958.82 & 1.03 & 38.59 \\
\hline Mullus barbatus & 1199.08 & 2056.73 & 1.02 & 40.75 \\
\hline Echelus myrus & 31.14 & 54.41 & 1.02 & 42.91 \\
\hline Arnoglossus laterna & 108.81 & 181.50 & 0.99 & 45.00 \\
\hline Zeus faber & 55.40 & 110.30 & 0.97 & 47.05 \\
\hline Uranoscopus scaber & 29.26 & 115.57 & 0.96 & 49.07 \\
\hline
\end{tabular}

sal fish community does not change towards a phylogenetically simplified set of species, but rather towards an equally or more diverse community which also presents higher abundance.

The Simpson index showed no difference in dominance between fish-farm and reference sites. In other words, there is no quantitative change similar to that obtained when r-selection species proliferate in the community in response to a severe disturbance.

The multivariate analyses showed that there was an effect of fish farming on the overall community structure; however, this was mainly attributed to quantitative rather than qualitative aspects, that is, there was a change in levels of abundance and/or biomass rather than replacement of species. The species found in the areas investigated during this study are those typically found in the Aegean Sea (Machias et al. 2001). Furthermore, in most cases, as shown by SIMPER analysis, this change was positive resulting in higher abundance and biomass close to the fish farming zones.

This type of effect on wild fish assemblages is likely to occur in any marine area affected by fish farming wastes and in fact we are not aware of any published study having proven the opposite. However, there are particular characteristics of the Mediterranean marine ecosystems which allow these effects to be more readily detectable than elsewhere: (1) the pronounced oligotrophy of the Eastern Mediterranean, the low nutrient levels (Friligos \& Gotsis-Skretas 1987) and low primary production (Sournia 1973); (2) the phosphorus-limitation of primary produc-

(Warwick \& Clarke 2001). Taxonomic distinctness indices describe features of this taxonomic spread and are now beginning to find application in environmental impact assessment, with growing evidence that, for a given number of species, perturbed communities usually comprise a more limited taxonomic spread (Brown et al. 2002, Warwick et al. 2002). Although the number of species is dependent on the sample size (i.e. on the number of individuals counted in the samples obtained), the taxonomic distinctness-based indices have been shown to be remarkably independent of sample size (Clarke \& Warwick 1998). Taking the overall picture into account, it seems that at sites close to fish farming zones, the overall structure of the demer- tion (Krom et al. 1991), at least for part of the year; and (3) the high water transparency (Ignatiades 1998), allowing the exploitation of nutrient resources deeper in the water column. The microtidal regime characterising this area is also important, since it imposes generally slower water renewal rates than in macrotidal areas, thereby allowing a longer residence time of nutrient-enriched water masses in coastal bays. Furthermore, in a multispecies fishery context such as the one of the eastern Mediterranean (Stergiou et al. 1997), the effects of fish farm presence are more likely to be important since the increased production affects the entire community, not only certain target species. Of course, these effects are also likely to be related to 
the level of production of the fish farms and the area topography: very low levels of production (e.g. of a small-sized farm in a highly exposed area) could go unnoticed, whereas extremely high levels in very enclosed areas are likely to result in significant effects.

In several parts of the world (Beveridge et al. 1996), and particularly in the Mediterranean (Pitta et al. 1999, Belias et al. 2003), it has been shown that the effects of fish farming on nutrients and chlorophyll concentration in the water column are hardly measurable and only over a short time-scale (Karakassis et al. 2001). This is probably related to the dispersive nature of the sites, which allows rapid advection and diffusion, but it is also likely that there is a rapid consumption and transfer towards higher trophic levels. In this case, the fish communities are probably a good indicator of the increased material flux since they are long-lived organisms integrating processes over longer time periods, and their predators are unlikely to respond promptly to an increase in their biomass.

The overall conclusion is that the presence of fish farming is likely to have positive effects (at least in terms of socio-economic aspects) on wild fish assemblages at the spatial scales investigated. These could involve an increase in wild fish biomass by an average factor of 2.8, as well as in a significant increase (by a factor of 2) in local fisheries landings (Machias et al. 2003) after the establishment of fish farming zones.

Acknowledgements. The authors would like to acknowledge support by the European Commission (Project AQCESS, Contract Q5RS-2000-31151) as well as the captain and the crew of RV 'Philia' for their assistance during the sampling surveys. Three anonymous reviewers provided comments that helped improve the manuscript.

\section{LITERATURE CITED}

Belias CV, Bikas VG, Dassenakis MJ, Scoullos MJ (2003) Environmental impacts of coastal aquaculture in Eastern Mediterranean Bays: the case of Astakos Gulf, Greece. Environ Sci Pollut Res 10:287-295

Beveridge MCM (1996) Cage aquaculture. Fishing News Books. Blackwell, Oxford

Brown BE, Clarke KR, Warwick RM (2002). Serial patterns of biodiversity change in corals across shallow reef flats in Ko Phuket, Thailand, due to the effects of local (sedimentation) and regional (climatic) perturbations. Mar Biol 141: 21-29

Brown JR, Gowen RJ, McLusky DS (1987) The effects of salmon farming on the benthos of a Scottish sea loch. J Exp Mar Biol Ecol 109:39-51

Caddy JF (1993) Towards a comparative evaluation of human impacts on fishery ecosystems of enclosed and semienclosed seas. Rev Fish Sci 1:57-95

Carrothers PJG (1980) Estimation of trawl door spread from wing spread. J Northw Atl Fish Sci 1:81-89

Carss DN (1990) Concetrations of wild and escaped fishes immediately adjacent to fish farm cages. Aquaculture 90(1):29-40
Carss DN (1994) Killing of piscivorous birds at Scottish fish farms, 1984-87. Biol Conserv 68 (2): 181-188

Clarke KR, Warwick RM (1994) Change in marine communities: an approach to statistical analysis and interpretation. Natural Environment Research Council, UK

Clarke KR, Warwick RM (1998) A taxonomic distinctness index and its statistical properties. J Appl Ecol 35:523-531

Clarke KR, Warwick RM (1999) The taxonomic distinctness measure of biodiversity: weighting of step lengths between hierarchical levels. Mar Ecol Prog Ser 184:21-29

Delgado O, Ruiz J, Perez M, Romero J, Ballestreros E (1999) Effects of fish farming on seagrass (Posidonia oceanica) in a Mediterranean bay: seagrass decline after loading cessation. Oceanol Acta 22:109-117

Dempster T, Sanchez-Jerez P, Bayle-Sempere JT, GiménezCasalduero F, Valle C (2002) Attraction of wild fish to seacage fish farms in the south-western Mediterranean Sea: spatial and short-term temporal variability. Mar Ecol Prog Ser 242:237-252

Fernandes TF, Eleftheriou A, Ackefors H, Eleftheriou M and 7 others (2001) The scientific principles underlying the monitoring of the environmental impacts of aquaculture. J Appl Ichthyol 17:181-193

Friligos N, Gotsis-Skretas O (1987) Relationships of phytoplankton with certain environmental factors in the South Evoikos Gulf (Greece). PSZN I: Mar Ecol 8:59-73

Gowen RJ, Bradbury NB (1987) The ecological impact of salmonid farming in coastal waters: a review. Oceanogr Mar Biol Annu Rev 25:563-575

Hall POJ, Holby O, Kollberg S, Samuelsson MO (1992) Chemical fluxes and mass balances in a marine fish cage farm. IV. Nitrogen. Mar Ecol Prog Ser 89:81-91

Holby O, Hall POJ (1991) Chemical fluxes and mass balances in a marine fish cage farm. II. Phosphorus. Mar Ecol Prog Ser 70:263-272

Holmer M, Kristensen E (1992) Impact of fish cage farming on metabolism and sulfate reduction of underlying sediments. Mar Ecol Prog Ser 80:191-201

Holmer M, Marba N, Terrados J, Duarte CM, Fortes MD (2002) Impacts of milkfish (Chanos chanos) aquaculture on carbon and nutrient fluxes in the Bolinao area, Philippines. Mar Pollut Bull 44:685-696

Holmer M, Pérez M, Duarte CM (2003) Benthic primary producers - a neglected environmental problem in Mediterranean maricultures? Mar Pollut Bull 46:1372-1374

Ignatiades L (1998) The productive and optical status of the oligotrophic waters of the Southern Aegean Sea (Cretan Sea), Eastern Mediterranean. J Plankton Res 20:985-995

Karakassis I (1998) Aquaculture and coastal marine biodiversity. Oceanis 24:271-286

Karakassis I, Smith CJ, Eleftheriou A (1996) Performance of neutral model analysis in a spatio-temporal series of macrobenthic replicates. Mar Ecol Prog Ser 137:173-179

Karakassis I, Tsapakis M, Hatziyanni E (1998) Seasonal variability in sediment profiles beneath fish farm cages in the Mediterranean. Mar Ecol Prog Ser 162:243-252

Karakassis I, Tsapakis M, Hatziyanni E, Papadopoulou KN, Plaiti W (2000) Impact of cage farming of fish on the seabed in three Mediterranean coastal areas. ICES J Mar Sci 57:1462-1471

Karakassis I, Tsapakis M, Hatziyanni E, Pitta P (2001) Diel variation of nutrients and chlorophyll in sea bream and sea bass cages in the Mediterranean. Fresenius Environ Bull 10:278-283

Krom MD, Kress N, Brenner S, Gordon LI (1991) Phosphorus limitation of primary productivity in the eastern Mediterranean Sea. Limnol Oceanogr 36:424-432 
La Rosa T, Mirto S, Mazzola A, Danovaro R (2001) Differential responses of benthic microbes and meiofauna to fish-farm disturbance in coastal sediments. Environ Pollut 112: $427-434$

Labropoulou M, Machias A, Tsimenides N (1999) Habitat selection and diet of the juvenile red porgy, Pagrus pagrus (Linnaeus, 1758) from the Cretan shelf. Fish Bull 97: 495-507

Machias A, Labropoulou M (2002) Intra-specific variation in resource use for the red mullet, Mullus barbatus. Estuar Coast Shelf Sci 55(4):565-578

Machias A, Somarakis S, Tsimenides N (1998) Bathymetric distribution and movements of red mullet Mullus surmuletus. Mar Ecol Prog Ser 166:247-257

Machias A, Vassilopoulou V, Vatsos D, Bekas P, Kallianiotis A, Papaconstantinou C, Tsimenides N (2001) Bottom trawl discards in the N. E. Mediterranean Sea. Fish Res 53: 181-195

Machias A, Somarakis S, Karakassis I, Neofytou C and 5 others (2003) Fish landing changes since the onset of aquaculture: two case studies. Proceedings of the 7 th Hellenic Symposium on Oceanography and Fisheries, Hersonissos, 6-9 May, 2003, book of abstracts, p 203

Machias A, Karakassis I, Labropoulou M, Somarakis S, Papadopoulou KN, Papaconstantinou C (2004) Changes in wild fish assemblages after the establishment of a fish farming zone in oligotrophic marine ecosystems. Estuar Coast Shelf Sci 60: 771-779

Mazzola A, Mirto S, Danovaro R (1999) Initial fish-farm impact on meiofaunal assemblages in coastal sediments of the Western Mediterranean. Mar Pollut Bull 38:1126-1133

Mazzola A, Mirto S, Danovaro R (2000) Fish-farming effects on benthic community structure in coastal sediments: analysis of meiofaunal resilience. ICES J Mar Sci 57:1454-1461

Mirto S, La Rosa T, Gambi C, Danovaro R, Mazzola A (2002) Nematode community response to fish-farm impact in the western Mediterranean. Environ Pollut 116:203-214

Pergent G, Mendez S, Pergent-Martini C, Pasqualini V (1999) Preliminary data on the impact of fish farming facilities on Posidonia oceanica meadows in the Mediterranean. Oceanol Acta 22:95-107

Pitta P, Karakassis I, Tsapakis M, Zivanovic S (1999) Natural versus mariculture induced variability in nutrients and plankton in the Eastern Mediterranean. Hydrobiologia 391:181-194

Editorial responsibility: Otto Kinne (Editor-in-Chief), Oldendorf/Luhe, Germany
Pohle G, Frost B, Findlay R (2001) Assessment of regional benthic impact of salmon mariculture within the Letang Inlet, Bay of Fundy. ICES J Mar Sci 58:417-426

Ruiz JM, Perez M, Romero J (2001) Effects of fish farm loadings on seagrass (Posidonia oceanica) distribution, growth and photosynthesis. Mar Pollut Bull 42:749-760

Smith C, Machias A, Giannoulaki M, Somarakis S, Papadopoulou KN, Karakassis I (2003) Diversity study of wild fish fauna aggregating around fish farm cages by means of remotely operated vehicle (ROV). Proceedings of the 7th Hellenic Symposium on Oceanography and Fisheries, Hersonissos, 6-9 May, 2003, book of abstracts, p 227

Somarakis S, Machias A (2002) Age, growth and bathymetric distribution of red Pandora (Pagellus erithrinus) on the Cretan shelf. J Mar Biol Assoc UK 82(1):149-160

Sournia A (1973) La production primaire planktonique en Méditerranée. Bull Étude Commun Méditerranée 5:1-128

Stergiou KI, Christou ED, Georgopoulos D, Zenetos A, Souvermezoglou C (1997) The Hellenic seas: physics, chemistry, biology and fisheries. Oceanogr Mar Biol Annu Rev 35:415-538

Tsimenides N, Machias A, Kallianiotis A (1992). Distribution patterns of triglids, (Pisces: Triglidae), on the Cretan shelf (Greece) and their interspecific associations. Fish Res 15: 83-103

Warwick RM, Clarke KR (1995) New 'biodiversity' measures reveal a decrease in taxonomic distinctness with increasing stress. Mar Ecol Prog Ser 129:301-305

Warwick RM, Clarke KR (2001) Practical measures of marine biodiversity based on relatedness of species. Oceanogr Mar Biol Annu Rev 39:207-231

Warwick RM, Asham CM, Brown AR, Clarke KR and 6 others (2002) Inter-annual changes in the biodiversity and community structure of the macrobenthos in Tees Bay and Tees estuary, UK, associated with local and regional environmental effects. Mar Ecol Prog Ser 234:1-13

Weston DP (1990) Quantitative examination of macrobenthic community changes along an organic enrichment gradient. Mar Ecol Prog Ser 61:233-244

Wu RSS (1995) The environmental impact of marine fish culture: towards a sustainable future. Mar Pollut Bull 31: 159-166

Zar JH (1984) Biostatistical analysis. Prentice-Hall, Englewood-Cliffs, NJ

Submitted: June 2, 2004; Accepted: September 28, 2004

Proofs received from author(s): February 17, 2005 